\title{
Peningkatan Kapasitas Tata Laksana Kesehatan Ternak Sapi Potong di Pelemrejo, Andong, Boyolali
}

\author{
Dian Meididewi Nuraini*, Sunarto, Nuzul Widyas, Ahmad Pramono, Sigit Prastowo \\ Program Studi Peternakan Fakultas Pertanian Universitas Sebelas Maret \\ *Corresponding author: dianmeididewi@staff.uns.ac.id
}

\begin{abstract}
ABSTRAK
Masyarakat Desa Pelemrejo, Kecamatan Andong, Kabupaten Boyolali mayoritas adalah petani yang memiliki usaha ternak sapi potong. Produksi ternak sapi sering kali terkendala masalah kesehatan ternak yang dapat menurunkan kualitas serta kuantitas daging sapi. Pengetahuan mengenai manajemen kesehatan sapi potong perlu diberikan kepada peternak untuk membantu meminimalisir kerugian yang terjadi akibat masalah kesehatan. Kegiatan ini bertujuan untuk memberikan pengetahuan kepada peternak mengenai manajemen kesehatan sapi potong. Metode kegiatan terdiri dari survei ke peternakan sapi potong, penyuluhan dan diskusi massal, serta pemberian bantuan obatobatan dan desinfektan ke peternak. Kunjungan ke peternakan di desa tersebut menunjukkan bahwa terdapat sapi yang menunjukkan kekurusan, kondisi kandang kotor dengan area penyimpanan pakan yang tidak sesuai standar. Penyuluhan dan diskusi massal dengan cara penyampaian materi secara langsung mengenai identifikasi kondisi kesehatan sapi, program sanitasi kandang, program pemberian obat cacing teratur, penyakit yang sering ditemukan pada sapi potong, serta pengobatan yang dapat dilakukan oleh peternak. Obat-obatan dan desinfektan diberikan kepada peternak untuk membantu dalam mengaplikasikan manajemen kesehatan ternak yang telah dijelaskan melalui penyuluhan. Secara keseluruhan dapat disimpulkan bahwa peternak dapat mengikuti materi penyuluhan yang diberikan dan berperan serta aktif dalam proses diskusi yang dilakukan.
\end{abstract}

Kata kunci: kesehatan ternak; peternak; sapi potong

\section{ABSTRACT}

Majority people of Pelemrejo Village, Andong Sub-district, Boyolali district are farmer who own beef cattle. The production of beef cattle is often constrained by beef cattle health problem which alter the quality and quantity of meat production. Understanding of beef cattle health management should be given to the farmer to reduce the possibility of economic loss due to beef cattle health problem. This program aimed to give understanding to the farmer about beef cattle health management. Method used in this program are survey to the farm, mass socialization and discussion, and distribution of cattle's drugs and disinfection. Based on survey, the condition of cattle housing in Pelemrejo Village was dirty with insufficient feed storage. Mass socialization and discussion was held directly with topic about identification of health condition of cattle, sanitation management, scheduled deworming program, common disease in beef cattle, and the application of medication in beef cattle. The drugs and disinfectant were given to the farmer as a support to implementation of health management in their farms. As conclusion, this program was conducted successfully with high enthusiasm form the farmer which can be seen form the participation during the activity.

Keywords: cattle health; farmer; beef cattle

\section{PENDAHULUAN}

Kesehatan ternak merupakan salah satu faktor yang berpengaruh terhadap keberhasilan usaha peternakan sapi potong. Penyakit yang menyerang ternak diketahui dapat menurunkan pembentukan daging serta produktivitas ternak karena gangguan penyerapan nutrisi (Abidin 2008; Triakoso 2009). Triakoso (2009) menyebutkan bahwa gangguan kesehatan hewan dapat merugikan peternak yang disebabkan oleh kematian ternak, biaya yang dikeluarkan untuk 
pengobatan, penurunan produksi, serta turunnya efisiensi pakan. Kerugian tersebut menunjukkan bahwa tata laksana kesehatan ternak penting diterapkan dalam usaha peternakan.

Desa Pelemrejo, Kecamatan Andong, Kabupaten Boyolali merupakan daerah pertanian yang juga menjadi lokasi peternakan sapi potong. Sapi potong dimanfaatkan sebagai sumber daging serta sumber pupuk bagi pertanian di daerah tersebut. Mayoritas ternak sapi potong di desa ini digunakan sebagai pendapatan cadangan sehingga aspek manajemen pemeliharaan secara keseluruhan belum memadai. Usaha peternakan di desa ini dijalankan menggunakan metode intensif dimana kandang sapi milik perorangan terletak di area rumah peternak. Salah satu permasalahan yang terjadi adalah belum adanya pelaksanaan manajemen kesehatan ternak yang baik oleh peternak. Rendahnya pelaksanaan manajemen kesehatan hewan berimbas kepada kerugian akibat adanya gangguan kesehatan ternak termasuk kerugian untuk pengobatan ternak oleh mantri atau dokter hewan, penurunan produksi, serta kematian ternak. Oleh karena itu, peternak memerlukan pemahaman mengenai tata laksana manajemen kesehatan ternak di Desa Pelemrejo. Manajemen kesehatan hewan berhubungan erat dengan usaha pencegahan infeksi dari agen-agen infeksi melalui upaya menjaga biosekuriti dengan menjaga higienitas dan sanitasi kandang, manajemen pakan yang baik, dan peningkatan daya tahan tubuh ternak melalui pemberian obat cacing dan multivitamin (LeBlanc et al. 2006; Lestari et al. 2020). Lestari et al. (2019) mengungkapkan bahwa biosekuriti melalui pelaksanaan higienitas dan sanitasi merupakan aspek penting untuk dijalankan di peternakan ada atau tidak adanya penyakit. Brennan et al. (2016) menjelaskan bahwa secara umum terdapat dua jenis peternak dalam hal penerapan manajemen kesehatan ternak, yaitu peternak yang tidak menerapkan biosekuriti tanpa keinginan untuk menerapkan biosekuriti di masa depan, serta peternak yang hanya menjalankan dalam waktu singkat. Peternak di Desa Pelemrejo merupakan peternak yang belum menjalankan biosekuriti serta belum memiliki keinginan di masa depan yang disebabkan karena rendahnya pengetahuan mengenai hal tersebut sehingga sering ditemukan ternak yang mengalami gangguan kesehatan. Tujuan pengabdian ini adalah untuk memberikan pengetahuan kepada peternak dalam mengenati manajemen kesehatan ternak di Desa Pelemrejo,
Kecamatan Andong, Kabupaten Boyolali sehingga dapat meminimalisir kerugian akibat gangguan kesehatan ternak.

\section{METODE}

\section{Waktu dan Tempat}

Pengabdian masyarakat ini dilakukan selama bulan Februari - Maret 2020, dengan target peserta adalah peternak sapi potong di Desa Pelemrejo, Kecamatan Andong, Kabupaten Boyolali. Peserta terdiri dari 29 orang peternak yang telah melakukan aktivitas beternak sapi selama minimal 2 tahun.

\section{Informasi awal dan materi penyuluhan}

Untuk mendapatkan informasi materi penyuluhan, maka dilakukan survei dilakukan dua minggu sebelum melaksanakan penyuluhan dengan tujuan mengetahui tata laksana manajemen kesehatan ternak di peternakan sapi potong di Desa Pelemrejo, Kecamatan Andong, Kabupaten Boyolali. Kegiatan survei dilakukan dengan pengamatan langsung kondisi kandang dan hewan serta wawancara kepada peternak untuk mengetahui gejala penyakit yang sering muncul. Hasil survei menjadi dasar penyiapan materi penyuluhan serta penyiapan obat-obatan yang akan diberikan. Pemberian penyuluhan ini dilakukan satu kali melalui tatap muka secara langsung. Materi yang diberikan berdasar dari informasi yang sebelumnya telah diberikan oleh tim survei atau peternak, sehingga materi yang dipilihkan paling tidak mewakili kebutuhan peternakan. Ukuran evaluasinya adalah kesadaran peternak untuk dapat memahami materi dan selanjutnya mampu untuk menggunakannya melalui contoh yang diberikan.

\section{Penyuluhan dan diskusi massal}

Penyuluhan dan diskusi massal dilaksanakan dalam pelaksanaan kegiatan pengabdian ini. Penyuluhan dilaksanakan dengan mengumpulkan seluruh peternak yang berjumlah 29 orang. Materi disampaikan secara langsung melalui ceramah dengan topik ciri-ciri hewan sehat dan sakit, faktor-faktor yang mempengaruhi kesehatan ternak, cara mencegah penyakit, faktor-faktor yang mempengaruhi kesehatan ternak (kualitas pakan, higienitas dan sanitasi kandang, daya tahan tubuh ternak), jenis-jenis penyakit serta penanganan, dan tata cara pemberian obat topikal dan obat cacing. Setelah penyampaian materi dilakukan diskusi 
bersama mengenai manajemen kesehatan ternak di desa tersebut. Selanjutnya peternak diberikan kebebasan untuk menentukan penggunaan metode terbaik sesuai dengan kondisinya masing-masing. Jadi pada intinya, penyuluhan ini adalah untuk menggugah kesadaran peternak akan Kesehatan ternak dan cara penanganannya.

\section{Pemberian obat-obatan dan desinfektan}

Pemberian obat-obatan disesuaikan dengan gejala penyakit yang sering terjadi di peternakan di Desa Pelemrejo. Adapun jenis obat-obatan yang diberikan yaitu antiseptik spray (Gusanex dan Limoxin LA), salep luka tetracycline (Ikacyline), obat cacing bolus (Albendazole), serta desinfektan (Benzaklin). Obat-obatan tersebut merupakan obat luar yang dapat digunakan tanpa pengawasan dokter hewan pada kasus-kasus penyakit ringan sehingga dapat digunakan oleh peternak secara langsung pada saat terjadi kasus-kasus tertentu untuk mencegah kondisi yang semakin parah.

\section{HASIL DAN PEMBAHASAN}

Sapi potong di Desa Pelemrejo, Kecamatan Andong, Kabupaten Boyolali berjumlah 30 ekor dengan tujuan pemeliharaan untuk penggemukan. Pemeliharaan dilakukan secara intensif dimana sapi dikandangkan sepanjang waktu dengan pemberian pakan sebanyak dua kali, pada pagi dan sore hari. Hasil survei menunjukkan bahwa terdapat permasalahan berupa tata letak kandang yang kurang baik, penyimpanan pakan yang terbuka dan berdekatan dengan area kotor, rendahnya pelaksanaan higiene dan sanitasi, tidak ada program pencegahan penyakit parasiter, dan sapi kurus. Kondisi kandang yang kurang baik terlihat pada seluruh kandang yang dimiliki oleh peternak. Kandang sapi potong di Desa Pelemrejo berlokasi di masing-masing rumah dari peternak tersebut. Kondisi kandang terlihat kotor dan belum ada saluran pembuangan limbah yang terpadu sehingga banyak kotoran yang menumpuk di sekitar kandang seperti yang terlihat pada Gambar 1.

Kotoran sapi seringkali dijadikan tempat perkembangbiakan lalat serta pertumbuhan parasit. Selain itu, penumpukan kotoran juga meningkatkan kemungkinan terjadinya kontaminasi feses pada pakan. Melalui siklus hidupnya, parasit akan melepaskan telur atau larvanya melaui feses, sehingga penumpukan feses di kandang meningkatkan kemungkinan terjadinya penyebaran parasit (Ritonga 2018). Penanganan feses yang kurang baik diketahui dapat menjadi media hidup untuk telur cacing pathogen seperti Strongylus sp, Fasciola sp., Paramphistomum, Moniezia sp, Toxocara vitulorum, dan Strongyloides spp. (Nugraheni 2015; Ritonga 2018).

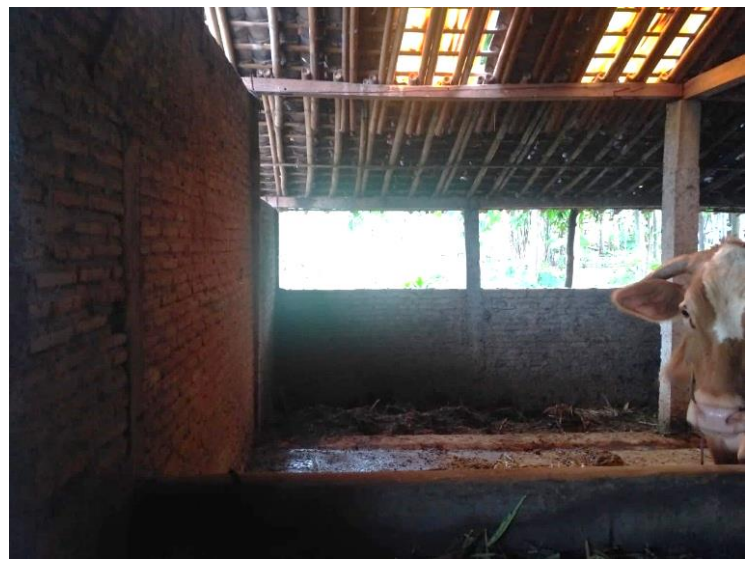

Gambar 1. Kondisi kandang sapi dengan penumpukan kotoran di dalamnya

Mayoritas kandang tidak memiliki gudang pakan untuk penyimpanan pakan yang menyebabkan tingginya kontaminasi. Pakan diletakkan di area terbuka di sekitar kandang yang tertutup atap, namun alas pakan tidak dibeli lapisan khusus dan berdekatan dengan area aliran air (Gambar 2). Pakan merupakan faktor penting dalam produksi ternak karena merupakan sumber nutrisi yang berperan dalam pertumbuhan, reproduksi, dan pemeliharaan tubuh (Susilawati 2016). Kondisi penyimpanan pakan yang kurang baik menyebabkan pakan tersebut rawan cemaran mikrobia seperti kapang dari famili Fusarium sp., Aspergilus sp., Mucor sp., dan Penicillium sp.,(Ahmad 2009). Kapang tersebut dapat ditemukan pada berbagai jenis pakan sapi seperti jagung, konsentrat, rumput, daun jagung, dedak padi, serta jerami padi (Ahmad 2009). Selain kapang, pakan yang tidak disimpan dengan baik juga rentang terhadap cemaran bakteri maupun telur atau larva cacing yang terbawa dari aliran air kotor sehingga dapat meningkatkan resiko terjadinya penyakit pada ternak.

Penyakit yang berhubungan dengan kontaminasi pakan dari kotoran adalah cacingan. Kasus cacingan dapat dicegah melalui pemberian obat cacing yang teratur, namun di Desa Pelemrejo, tidak ada program pemberian obat cacing yang teratur oleh peternak. Penyakit cacingan dapat menyebabkan kerusakan vili-vili 
usus yang berimbas ke penurunan penyerapan nutrisi makanan (Larasati \& Hartono 2017; Zalizar 2017). Pemberian obat cacing merupakan salah satu upaya yang penting untuk memutus siklus hidup parasit (Ginting 2019). Pemberian obat cacing untuk pencegahan umum diberikan secara berkala setiap 3-6 bulan sekali meskipun hewan tidak menunjukan gejala cacingan (Zalizar 2017). Hewan yang telah terinvestasi cacing, maka pengobatan diulang dalam waktu kurang dari satu bulan. Salah satu ciri-ciri adanya cacingan adalah kekurusan yang terlihat pada beberapa sapi di Desa Pelemrejo (Gambar 3). Rendahnya pengetahuan peternak mengenai gejala cacingan, penularan parasit cacing, pengendalian dan pengobatan merupakan salah satu permasalahan pada usaha peternakan sapi potong di Desa Pelemrejo.

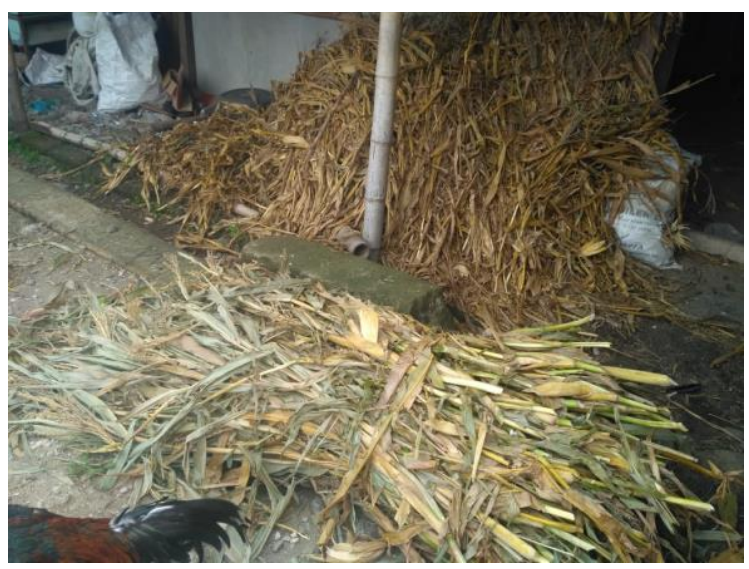

Gambar 2. Lokasi penyimpanan pakan ternak yang langsung bersinggungan dengan aliran buangan air

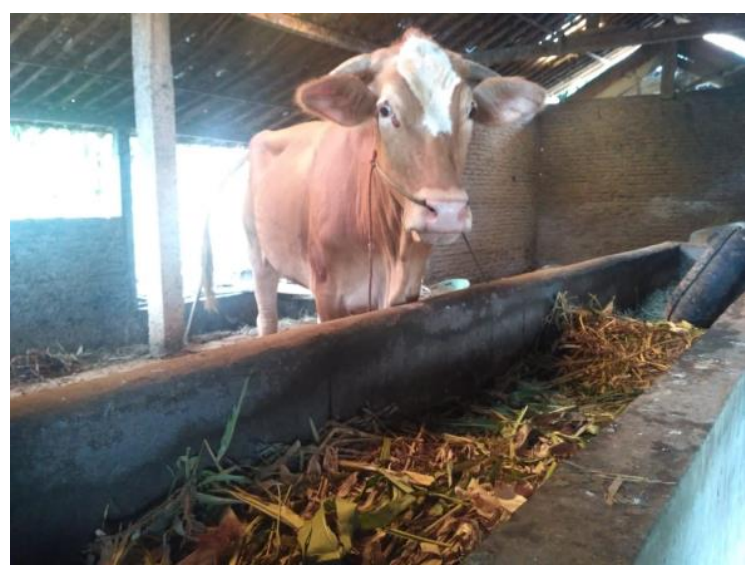

Gambar 3. Salah satu sapi di Desa Pelemrejo dengan kondisi tubuh kurus

Survey yang dilakukan menemukan beberapa gejala penyakit yang sering muncul pada sapi di Desa Pelemrejo. Gejala-gejala yang sering terlihat adalah kelukaan pada kaki, adanya belatung pada luka, sapi kurus, lesu, lemah, diare, kembung, dan nafsu makan turun. Berdasarkan wawancara diketahui bahwa peternak masih belum memahami membedakan sapi sakit dan sehat pada gejala awal sehingga biasanya penanganan dilakukan jika gejala sudah mulai parah. Gejala-gejala yang diutarakan di atas mengarah ke beberapa penyakit seperti miasis atau adanya belatung pada luka terbuka karena kontaminasi telur lalat, cacingan dengan gejala kekurusan, lemah, lesu, tidak nafsu makan, diare dan mata berair serta bloat yang merupakan penyakit metabolik akibat kandungan pakan yang tidak seimbang (Wardhana \& Muharsini 2005; Susilawati 2016). Penyakit-penyakit tersebut dapat dihindari dengan cara menjaga higienitas serta sanitasi kandang. Berdasarkan hasil survei tersebut, dapat diketahui bahwa permasalahan utama dalam manajemen kesehatan sapi potong di Desa Pelemrejo, Kecamatan Andong, Kabupaten Boyolali adalah kondisi kandang yang kotor dikarenakan rendahnya penerapan higientias dan sanitasi kandang, penyimpanan pakan yang tidak sesuai, tidak adanya program pengendalian parasit yang sesuai, dan kurangnya pemahaman peternak dalam mendeteksi sapi sakit sedini mungkin,. Permasalahan ini dirangkum dan digunakan sebagai materi dalam penyampaian penyuluhan manajemen tatalaksana kesehatan sapi potong.

Penyuluhan massal secara langsung dilakukan di Kantor Kepala Desa Pelemrejo, Kecamatan Andong, Kabupaten Boyolali (Gambar 4). Sebanyak 29 peserta yang merupakan peternak dan perangkat desa mengikuti kegiatan ini. Materi yang disampaikan melalui ceramah adalah ciri sapi sehat dan sakit yang dapat dilihat melalui tingkah laku abnormal seperti mata sayu, penurunan nafsu makan, kenaikan frekuensi nafas, suara nafas keras, lemas, lesu, dan adanya leleran berlebihan di hidung. Materi ini disampaikan untuk memberikan wawasan kepada peternak dalam mengetahui kondisi kesehatan sapi berdasarkan pengamatan. Identifikasi adanya gangguan kesehatan hewan sedini mungkin memiliki segi positif dalam mengurangi biaya penanganan penyakit, meningkatkan angka kesembuhan, dan mengurangi kematian sehingga mengurangi kerugian peternak (Susilawati 2016).

Materi selanjutnya yaitu faktor-faktor yang mempengaruhi kesehatan ternak yaitu kualitas pakan, ketahanan imunitas hewan, serta 
kondisi dan kebersihan lingkungan kandang. Kualitas pakan terdiri dari kandungan nutrisi yang seimbang, jumlah cukup, dan bebas dari zat kimia berbahaya dengan penekanan untuk mencegah pencemaran melalui penyimpanan yang baik. Peternak diberikan wawasan untuk mengenai pakan yang baik bagi sapi serta penyimpanan yang sesuai untuk mengurangi terjadinya kontaminasi dengan cara menyimpan pakan di dalam gudang pakan tersendiri yang jauh dari aliran kotoran.

Penerapan higienitas dan sanitasi kandang terdiri dari: pembersihan kandang teratur menggunakan desinfektan minimal 2 minggu sekali, menjaga kebersihan peternak baik saat akan masuk maupun keluar kandang, serta menjaga kebersihan hewan ternak dengan mencegah adanya lalat ataupun kotoran yang menumpuk di sekitarnya. Peningkatan daya tahan tubuh hewan dapat ditingkatkan melalui pemberian obat cacing yang teratur serta pemberian multivitamin. Dalam penyuluhan ini turut disampaikan cara-cara pencegahan penyakit cacing melalui pemberian obat cacing yang sesuai setiap 3-6 bulan untuk upaya pencegahan penularan dan pemutusan siklus hidup cacing. Obat cacing diberikan secara peroral atau melalui mulut dan dapat menggunakan obat berspektrum luas seperti Albendazole. Selain itu, peternak diberi pemahaman mengenai pentingnya multivitamin dalam menjaga kesehatan ternak. Multivitamin umumnya dapat diberikan secara berkala melalui suntikan atau peroral namun harus di bawah pengawasan dokter hewan maupun mantri hewan.

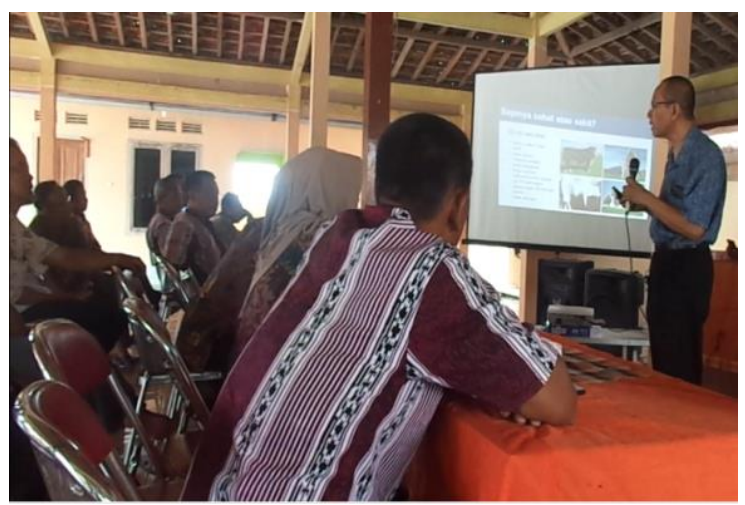

Gambar 4. Penjelasan materi manajemen kesehatan ternak sapi potong

Materi selanjutnya adalah penyakitpenyakit yang sering ditemukan pada sapi potong. Penyakit-penyakit tersebut terdiri dari pink eye, anthraks, cacingan, bloat, septichaemia epizootica, brucellosis, dan scabies. Setelah penyampaian materi, dilakukan diskusi. Dalam diskusi, peternak aktif memberikan pertanyaan serta tanggapan dari materi yang telah disampaikan atau mengenai pertanyaan yang disampaikan oleh peternak lain. Berdasarkan diskusi diketahui, peternak banyak yang menanyakan mengenai pengobatan yang dapat dilakukan pada ternak yang mengalami gangguan kesehatan seperti kelukaan, sapi lemas, dan pencegahan cacingan. Berdasarkan pertanyaan tersebut, dijelaskan pengobatan yang dapat diberikan oleh peternak seperti pemberian obat-obatan topikal untuk luka berupa antiseptik spray dan salep, pemberian tambahan vitamin bagi sapi-sapi yang lemas, dan pemberian obat cacing berkala untuk mencegah kasus cacingan.

Rangkaian selanjutnya dalam kegiatan pengabdian ini adalah pemberian bantuan berupa obat-obatan kepada peternak (Gambar 5). Obatobatan yang diberikan berupa obat-obatan luar yang dapat digunakan oleh peternak tanpa pengawasan dokter hewan. Obat-obatan ini diberikan berdasarkan dari hasil survei mengenai kebutuhan peternak di daerah ini. Obat-obatan ini terdiri dari antiseptik spray Gusanex dan Limoxin LA, salep luka Ikacycline, serta obat cacing Albendazole bolus. Obat-obatan yang diberikan dijelaskan lebih lanjut mengenai aplikasi penggunaannya. Antiseptik spray berfungsi untuk mengurangi infeksi serta mencegah miasis pada luka yang ada di tubuh maupun ekstremitas sapi dengan cara membunuh larva lalat. Obat ini diaplikasikan langsung ke daerah kulit yang luka dengan cara disemprot sehingga peternak dapat melakukan pengobatan dengan mudah. Antiseptik spray tersebut tidak dapat digunakan di aera sensitif yang dekat dengan mukosa, seperti sekitar mata, dubur, maupun vulva. Pengobatan kelukaan untuk area tersebut dapat menggunakan salep luka yang juga diberikan pada kegiatan ini. Obat cacing yang diberikan adalah Albendazole yang memiliki efektivitas yang tinggi dalam mengeleminasi berbagai macam cacing patogen pada sapi. Selain obat-obatan, untuk mendukung penerapan higienitas dan sanitasi kandang, desinfektan (Benziklin) juga diberikan pada pengabdian ini. Desinfektan ini memiliki tingkat efektivitas yang tinggi untuk membunuh mikrobia yang sering mengkontaminasi kandang. Diharapkan dari kegiatan ini, pengetahuan peternak mengenai tata laksana manajemen kesehatan ternak meningkat serta adanya penerapan manajemen kesehatan ternak di Desa Pelemrejo. 


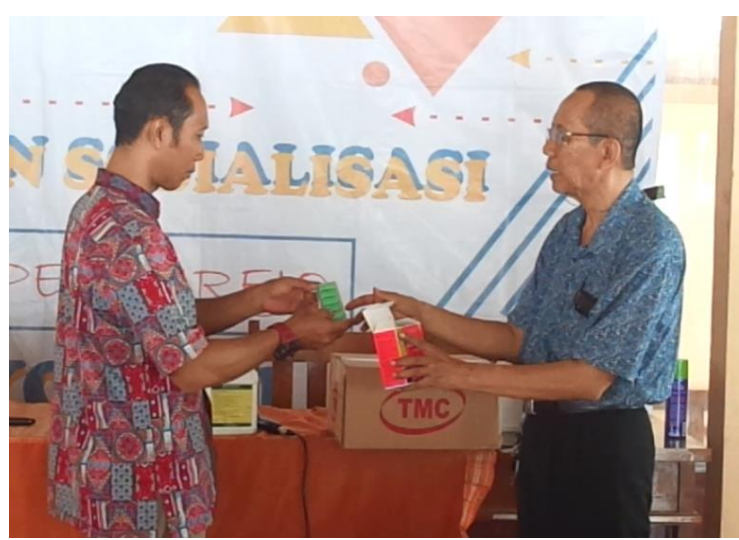

Gambar 5. Penjelasan penggunaan obat-obatan yang diberikan

\section{KESIMPULAN}

Kegiatan pengabdian ini berjalan dengan lancar dengan partisipasi aktif peternak dalam proses survei hingga diskusi massal. Kegiatan ini diharapkan dapat memberikan pengetahuan mengenai manajemen kesehatan dan sekaligus menggugah kesadaran peternak tentang arti kesehatan di peternakan sapi potong. Harapannya adalah apabila peternak melaksanakan manajemen kesehatan seperti yang disampaikan maka peternak dapat mengurangi kerugian akibat gangguan kesehatan ternak.

\section{UCAPAN TERIMA KASIH}

Penulis menyampaikan terima kasih kepada LPPM UNS yang telah memberikan pendanaan melalui P2M PNBP UNS Skema Hibah Pengabdian Grup Riset tahun 2020. Tidak lupa, penulis juga mengucapakan terima kasih kepada perangkat Desa Pelemrejo, Kecamatan Andong, Kabupaten Boyolali, peternak sapi potong di Desa Pelemrejo, serta seluruh mahasiswa yang terlibat dalam program pengabdian ini.

\section{DAFTAR PUSTAKA}

Abidin I.Z. (2008). Penggemukan Sapi Potong. Jakarta: AgroMedia.

Ahmad R.Z. (2009). Cemaran Kapang Pada Pakan dan Pengendaliannya. Jurnal Litbang Pertanian 28(1), 15-20. http://dx.doi.org/10.21082/jp3.v28n1.200 9.p15\%20-\%2022.

Brennan, M. L., N. Wright, W. Wapenaar, S. Jarratt, P. Hobson-West, I. F. Richens, J. Kaler, H. Buchanan, J. N. Huxley, and H.
M. O'Connor. 2016. Exploring attitudes and beliefs towards implementing cattle disease prevention and control measures: A qualitative study with dairy farmers in Great Britain. Animals 6(10):61. https://doi.org/10.3390/ani6100061.

Ginting R.B. (2019). Program Manajemen Pengobatan Cacing pada Ternak di Kelompok Tani Ternak Kesuma Maju Desa Jatikesuma Kecamatan Namorambe. JASA PADI 4 (1), 43-50. Retreived from http://jurnal.pancabudi.ac.id/index.php/ja sapadi/article/view/605

Larasati H. \& Hartono M. (2017). Prevalensi Cacing Saluran Pencernaan Sapi Perah Periode Juni-- Juli 2016 pada Peternakan Rakyat di Provinsi Lampung. Jurnal Riset dan Inovasi Peternakan (Journal of Research and Innovation of Animals) 1(1), 8-15. Retreived from http://jrip.fp.unila.ac.id/index.php/JRIP/a rticle/view/73

LeBlanc S.J., Lissemore K.D., Kelton D.F., Duffield T.F. \& Leslie K.E. (2006). Major Advances in Disease Prevention in Dairy Cattle. Journal of Dairy Science 89(4), 1267-79.

https://doi.org/10.3168/jds.S00220302(06)72195-6.

Lestari V., Sirajuddin S., Saleh I. \& Indah K. (2020). Perilaku Peternak Sapi Potong terhadap Pelaksanaan Biosekuriti. Prosiding Seminar Nasional Teknologi Peternakan dan Veteriner, pp. 263-71. http://dx.doi.org/10.14334/Pros.Semnas. TPV-2019-p.251-259

Nugraheni N. (2015). Identifikasi cacing endoparasit pada feses sapi potong sebelum dan sesudah proses pembentukan biogas digester fixed-dome. Students $e$ Journal 4(3), 1-7. Retreived from http://jurnal.unpad.ac.id/ejournal/article/v iew/6928/3243.

Ritonga M.Z. (2018). Identifikasi Telur Cacing Pada Sampel Feses Sapi Potong Pada KTT Kesuma Maju Desa Jatikesuma Kecamatan Namorambe. JASA PADI 3(1), 1-7. Retreived from http://jurnal.pancabudi.ac.id/index.php/ja sapadi/article/view/247.

Susilawati T. (2016). Industri Sapi Potong. Malang: Universitas Brawijaya Press.

Triakoso N. (2009). Aspek Klinik dan Penularan pada Pengendalian Penyakit Ternak. 
Surabaya: Departemen Klinik Veteriner PKH Universitas Airlangga.

Wardhana A.H. \& Muharsini S. (2005). Kasus Myasis yang disebabkan oleh Chrysomya bezziana di Pulau Jawa. Prosiding Seminar Nasional Teknologi Peternakan dan Veteriner. Bogor, pp. 12-23. Retreived from https://www.researchgate.net/profile/Apri 1

Wardhana/publication/281560865_Kasus
_Myasis_yang_disebabkan_oleh_Chryso mya_bezziana_di_Pulau_Jawa/links/55f7 76c808aeafc8ac0159f8.pdf.

Zalizar L. (2017). Helminthiasis saluran cerna pada sapi perah. Jurnal Ilmu-Ilmu Peternakan 27(2), 1-7. Retreived from https://www.academia.edu/download/569 95267/285-889-2-PB.pdf. 